\title{
CCL1 Gene
}

National Cancer Institute

\section{Source}

National Cancer Institute. CCL1 Gene. NCI Thesaurus. Code C24766.

This gene is involved in the regulation and modulation of inflammatory processes. 